\title{
Halophytes a Resource for the Future in Arid Regions of Kachchh
}

\author{
Jagruti P Shah* \\ Earth and Eco-science Research Institute, India
}

Submission: May 08, 2017; Published: May 23, 2017

"Corresponding author: Jagruti P Shah, Earth and Eco-science Research Institute, Madhapar-Bhujodi Highway, Bhuj- Kachchh , Gujarat, Indi, Email: jhsphd@gmail.com

\section{Mini Review}

Soil and water salinity places major constraints on plant growth in arid and coastal regions. A wide range of plant species grows naturally on the coastal and inland saline areas such as salt marshes and salt deserts (halophytes), which survive salt concentration equal to or greater than that of seawater. Under those extreme conditions of soil or water salinity where no

crop of agricultural interest can be grown it is possible to imagine dedicated halophyte plantations for forage production, soil rehabilitation, bioenergy generation, landscaping, carbon dioxide sequestering and a number of other useful purposes. The wide variety of halophytes and of their characters permits to envision a profitable use of vast barren extensions of saline lands by selecting the appropriate species best fitting local conditions.

Table 1: Possible uses of halophytes under various conditions

\begin{tabular}{|c|c|c|}
\hline Soil & Water & Principal Possible Actions \\
\hline Coastal lands & Sea water & $\begin{array}{c}\text { Fixing dunes, landscaping, growing } \\
\text { mangroves, fodder production, Various scopes }\end{array}$ \\
\hline Inland Saline Area (Irrigated) & Brackish/Saline water & $\begin{array}{c}\text { Erosion control, fodder production, soil } \\
\text { rehabilitation, agricultural production }\end{array}$ \\
\hline Inland Saline Area (dry) & Rain fresh/brackish water & \\
\hline Salinized Agriculture lands & fresh/brackish water & Soil protection, agriculture production \\
\hline Endangered agricultural lands & &
\end{tabular}

Source: V Sardo and A Hamdy.

All the possible actions listed in the Table 1 can be easily undertaken after an accurate plant selection but of course a preliminary analysis assessing their environmental, economic and social feasibility is required. It is worthless, saline lands and water are used to grow dedicated halophytes and produce some useful. In their some externalities are taken for some benefits such as social benefits depending on soil protection against water or wind erosion, biodiversity enhancement, the creation of shelters for wildlife, the protection of atmosphere quality, through the production of biofuels and the mitigation of the greenhouse effect through the capture of $\mathrm{CO2}$. Introducing halophytes or salt tolerant crops in the rotation can significantly help in keeping a low salt level in saline areas.

This small but diverse group of plants can fulfill almost every requirement of human beings especially those related to food, fodder, fuel, medicines, agricultural and so on. In Kachchh, distribution of halophytes is considerable because of desert, hills, ranns and long coast line. Kachchh district stretches between $22041^{\prime} 11^{\prime \prime}$ to $24041^{\prime} 47^{\prime \prime} \mathrm{N}$ latitude, and between 680
9' 46" to 710 54' 47" E longitude. Administratively, the district is divided into ten talukas, out of that coastal area is divided in to seven coastal talukas i.e. Lakhpat, Abdasa, Mandvi, Mundra, Anjar, Gandhidham and some part of Bhachau. The western part

of great Rann of Kachchh falls under the category of coastal desert ecosystem. Due to its low lying nature, the marine water encroaches and spreads over a fairly vast area. Consequently the water and soil of those particular areas become extremely saline due to prolonged evaporation and form a marshy land.

The coastal system of Kachchh includes with rocky cliffs and sandy shores, beaches, muddy coast, coastal desert of great and little Rann of Kachchh and special Economic Zones. The land in between the mainland and immediately behind the inner edge of the shore zone i.e. behind the innermost limit of the tidal impact areas during storms and highest tides is known as coast land [1]. The coastal land is usually covered with dry coastal beach vegetation, beach forest of sandy and rocky habitat types, wet coastal mangroves, salt marshes, seaweeds, sea grasses, coral 
reefs and associated sub tidal benthos [2]. With its $406 \mathrm{~km}$ length, Kachchh coast constitute about $25.37 \%$ of the coastal stretch of Gujarat. The Kachchh coastal land is covered with wet and dry with sand dune areas (Figure 1). Looking to the incredible potential of Halophytes and their unsuspected value a basic research was started on this subject by the author in Kachchh district of Gujarat state.

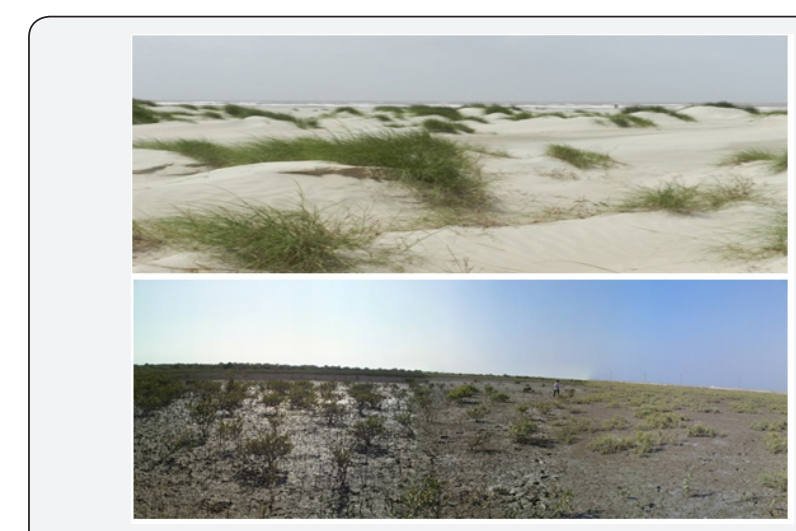

Figure 1: View of Dry and Wet Coastal area of Kachchh.

The study recorded more than 100 plants survive as halophytes in coastal Kachchh [3]. Sand dunes is having some of the interesting plant communities which are essential for ecological security i.e. Commiphora wightii Halophyrum mucronatum, Heliotropium bassiferum, Asparagus racemosus, Urochondra setulosa, Leptadenia pyrotechnica, Ipomoea pescaprae etc. The Kachchh coastal vegetation is characterized by the presence of the Mangroves (Avicennia marina) and associated several halophytes i.e. Tamarix troupii, Salicornia brachiata, Salsola baryosma, Sesuvium sesuvioides, Limonium stocksii need to the ecological security for well development. It is the goal of this article to demonstrate the potential of halophytes and salt tolerant glycophytes in taking advantage of those barren and abandoned marginal lands that are commonly believed useless or waste lands. A vast, very promising field is now facing the research on halophyte for the researcher. This is an attractive option of research and implementation with saline water and soils in the scarcity of fresh water. It is therefore recommended that halophytes as a resource for future in arid lands.

\section{Acknowledgement}

The author is grateful to DST (Department of Science and Technology - women scientist scheme WOS- A), which funded this project. This study was conducted as a part of a project on "Distribution, abundance and taxonomic status of halophytes in coastal and near coastal region of Kachchh, Gujarat".

\section{References}

1. Banerjee LK, Rao TA, Sastry ARK, Ghosh D (2002) Diversity of Coastal Plant Communities in India. ENVIS-EMCB-Botanical Survey of India, Ministry of Environment and Forest, Kolkata, India, p. 524.

2. Goldberg ED (1993) Competitors for coastal ocean space. Oceanus 36(1): 12-18.

3. Shah J, Thivakaran GA (2014) Distribution, abundance and taxonomic status of halophytes in coastal and near coastal region of Kachchh, Gujarat, India.

\section{Your next submission with Juniper Publishers will reach you the below assets}

- Quality Editorial service

- Swift Peer Review

- Reprints availability

- E-prints Service

- Manuscript Podcast for convenient understanding

- Global attainment for your research

- Manuscript accessibility in different formats

( Pdf, E-pub, Full Text, Audio)

- Unceasing customer service

Track the below URL for one-step submission https://juniperpublishers.com/online-submission.php 